UDC 330.46

http://doi.org/10.21272/mmi.2019.3-04

\author{
JEL Classification: C80, M2, M4
}

Tetiana Zatonatska,

D.Sc., Professor, Taras Shevchenko National University of Kyiv, Ukraine

Oleksandr Dluhopolskyi,

D.Sc., Professor, Ternopil National Economic University, Ternopil, Ukraine

\title{
MODELLING THE EFFICIENCY OF THE CLOUD COMPUTING IMPLEMENTATION AT ENTERPRISES
}

\begin{abstract}
The article describes the main characteristics, types and properties of cloud computing. The most widespread cloud technologies in Ukraine are analyzed. It is identified that the largest share among users of cloud technologies in Ukraine currently belong to large holdings, IT companies, commercial enterprises and banks, but other sectors of business are also involved in the development of these services. The aim of the article is to develop the methodology for evaluating the efficiency of cloud technologies implementation at enterprises and its experimental verification. The economic component of the cloud computing implementation at enterprises (expenditures and revenues of both cloud technology owners and users) is considered. The efficiency of using cloud computing at enterprises is proved. It is found that organizations usually do not use the power of their personal data centers to a full extent. This leads to idle equipment, extra cost on maintenance and servicing of hardware, amortization, staff salaries and etc. The feasibility of transition of enterprises to cloud computing in such situations has been proved, which considerably reduce the costs of the enterprise due to the absence of need for hardware and necessary staff to support the operation of information systems. Usability of the methodology of total cost of ownership in evaluating the effectiveness of using services for the enterprise has been proved. The proposed methodology compares the main costs of using personal data centers and the cost of using cloud computing. It is experimentally proven that in most cases, the cost of maintaining personal data center (PDC) is higher than the cost of cloud services. It is also proved that the efficiency of cloud technology operation depends on the internal structure and organization of computing processes inside the systems, as well as on external factors such as the size of enterprises-clients, industries, costs for the organization of data centers, etc. Cloud computing is an advanced technology which has future prospects and is cost-effective for both enterprise users and provider organizations.

Keywords: cloud computing, distributed database, enterprise cloud technologies, cloud computing efficiency, cloud architecture.
\end{abstract}

Introduction. The concept of cloud computing was introduced not too long ago, it is by far the strongest trend in the IT market, but indeed the old concept of the time allocation, considering the modern development of technical means, is hidden under a big name. Therefore, it can be noted that cloud computing is not a revolution, but only a new evolutionary spiral of the IT industry development. With the principle of time-sharing, you can achieve greater resource efficiency. It should be mentioned that the first ideas that indirectly touched on what later became cloud computing belong to the 1970's1980 's. However, the date refers to the modern history of cloud computing was 2006, when Amazon, which was already one of the largest at that time, introduced its web services infrastructure that was able to provide the user not only with hosting but also to provide remote computing power to the client. Newcomers have been embraced and endorsed by giants such as Google, Sun and IBM, and in 2008 Microsoft has expressed its interest in the industry.

Literature Review. The US National Institute of Standards and Technology (NIST) has created a working definition of cloud computing. According to NIST, cloud computing is a «model for enabling convenient, on-demand network access to a shared pool of configurable computing resources (e.g., networks, servers, storage, applications, and services) that can be rapidly provisioned and released with minimal management effort or service provider interaction» (Mell and Grance, 2011; Buyya, et al., 2008;

Cite as: Zatonatska,T., Dluhopolskyi, O. (2019). Modelling the Efficiency of the Cloud Computing Implementation at Enterprises. Marketing and Management of Innovations, 3, 45-59. http://doi.org/10.21272/mmi.2019.3-04 
Gohin, et al., 2012). There are five essential characteristics of cloud computing: on-demand self-service, broad network access, resource pooling, rapid elasticity, and measured service (table 1).

\section{Table 1. Essential characteristics of cloud computing}

\begin{tabular}{|l|l|}
\hline Characteristic & \multicolumn{1}{|c|}{ Definition } \\
\hline $\begin{array}{l}\text { On-demand } \\
\text { self-service }\end{array}$ & $\begin{array}{l}\text { A consumer can unilaterally provision computing capabilities, such as server time } \\
\text { and network storage, as needed automatically without requiring human interaction } \\
\text { with each service provider }\end{array}$ \\
\hline $\begin{array}{l}\text { Broad network } \\
\text { access }\end{array}$ & $\begin{array}{l}\text { Capabilities are available over the network and accessed through standard } \\
\text { mechanisms that promote use by heterogeneous thin or thick client platforms (e.g., } \\
\text { mobile phones, tablets, laptops, and workstations) }\end{array}$ \\
\hline $\begin{array}{l}\text { Resource } \\
\text { pooling }\end{array}$ & $\begin{array}{l}\text { The provider's computing resources are pooled to serve multiple consumers using a } \\
\text { multi-tenant model, with different physical and virtual resources dynamically } \\
\text { assigned and reassigned according to consumer demand. There is a sense of } \\
\text { location independence in that the customer generally has no control or knowledge } \\
\text { over the exact location of the provided resources but may be able to specify location } \\
\text { at a higher level of abstraction (e.g., country, state, or datacenter). Examples of } \\
\text { resources include storage, processing, memory, and network bandwidth }\end{array}$ \\
\hline $\begin{array}{l}\text { Rapid } \\
\text { elasticity }\end{array}$ & $\begin{array}{l}\text { Capabilities can be elastically provisioned and released, in some cases } \\
\text { automatically, to scale rapidly outward and inward commensurate with demand. To } \\
\text { the consumer, the capabilities available for provisioning often appear to be unlimited } \\
\text { and can be appropriated in any quantity at any time }\end{array}$ \\
\hline $\begin{array}{l}\text { Measured } \\
\text { service }\end{array}$ & $\begin{array}{l}\text { Cloud systems automatically control and optimize resource use by leveraging a } \\
\text { metering capability at some level of abstraction appropriate to the type of service } \\
\text { (e.g., storage, processing, bandwidth, and active user accounts). Resource usage } \\
\text { can be monitored, controlled, and reported, providing transparency for both the } \\
\text { provider and consumer of the utilized service }\end{array}$ \\
\hline
\end{tabular}

Sources: (Mell and Grance, 2011; Ahmed and Hussan, 2018)

There are four service models of cloud computing (table 2): SaaS, PaaS, laaS, and CaaS. And also can be four deployment models of it (table 3): private, community, public, and hybrid.

Table 2. Service models of cloud computing

\begin{tabular}{|c|c|c|c|}
\hline $\begin{array}{c}\text { Software as a Service } \\
\text { (SaaS) }\end{array}$ & $\begin{array}{c}\text { Platform as a Service } \\
\text { (PaaS) }\end{array}$ & $\begin{array}{l}\text { Infrastructure as a } \\
\text { Service (laaS) }\end{array}$ & $\begin{array}{c}\text { Communication as a } \\
\text { Service (CaaS) }\end{array}$ \\
\hline $\begin{array}{l}\text { The capability provided } \\
\text { to the consumer is to use } \\
\text { the provider's } \\
\text { applications running on a } \\
\text { cloud infrastructure. The } \\
\text { applications are } \\
\text { accessible from various } \\
\text { client devices through } \\
\text { either a thin client } \\
\text { interface, such as a web } \\
\text { browser (e.g., web-based }\end{array}$ & $\begin{array}{l}\text { The capability } \\
\text { provided to the } \\
\text { consumer is to deploy } \\
\text { onto the cloud } \\
\text { infrastructure } \\
\text { consumer-created or } \\
\text { acquired applications } \\
\text { created using } \\
\text { programming } \\
\text { languages, libraries, } \\
\text { services, and tools }\end{array}$ & $\begin{array}{l}\text { The capability provided } \\
\text { to the consumer is to } \\
\text { provision processing, } \\
\text { storage, networks, and } \\
\text { other fundamental } \\
\text { computing resources } \\
\text { where the consumer is } \\
\text { able to deploy and run } \\
\text { arbitrary software, which } \\
\text { can include operating } \\
\text { systems and }\end{array}$ & $\begin{array}{c}\text { A CaaS } \\
\text { model allows a CaaS } \\
\text { provider's business } \\
\text { customers to } \\
\text { selectively deploy } \\
\text { communications } \\
\text { features and services } \\
\text { throughout their } \\
\text { company on a pay- } \\
\text { as-you-go basis for } \\
\text { service(s) used. }\end{array}$ \\
\hline
\end{tabular}


Continued Table 2

\begin{tabular}{|c|c|c|c|}
\hline $\begin{array}{c}\text { Software as a Service } \\
\text { (SaaS) }\end{array}$ & $\begin{array}{c}\text { Platform as a Service } \\
\text { (PaaS) }\end{array}$ & $\begin{array}{c}\text { Infrastructure as a } \\
\text { Service (laaS) }\end{array}$ & $\begin{array}{c}\text { Communication as a } \\
\text { Service (CaaS) }\end{array}$ \\
\hline $\begin{array}{l}\text { email), or a program } \\
\text { interface. The consumer } \\
\text { does not manage or } \\
\text { control the underlying } \\
\text { cloud infrastructure } \\
\text { including network, } \\
\text { servers, operating } \\
\text { systems, storage, or } \\
\text { even individual } \\
\text { application capabilities, } \\
\text { with the possible } \\
\text { exception of limited user- } \\
\text { specific application } \\
\text { configuration settings }\end{array}$ & $\begin{array}{l}\text { supported by the } \\
\text { provider. The } \\
\text { consumer does not } \\
\text { manage or control the } \\
\text { underlying cloud } \\
\text { infrastructure including } \\
\text { network, servers, } \\
\text { operating systems, or } \\
\text { storage, but has } \\
\text { control over the } \\
\text { deployed applications } \\
\text { and possibly } \\
\text { configuration settings } \\
\text { for the application- } \\
\text { hosting environment }\end{array}$ & $\begin{array}{l}\text { applications. The } \\
\text { consumer does not } \\
\text { manage or control the } \\
\text { underlying cloud } \\
\text { infrastructure but has } \\
\text { control over operating } \\
\text { systems, storage, and } \\
\text { deployed applications; } \\
\text { and possibly limited } \\
\text { control of select } \\
\text { networking components } \\
\text { (e.g., host firewalls) }\end{array}$ & $\begin{array}{l}\text { CaaS is designed on } \\
\text { a utility-like pricing } \\
\text { model that provides } \\
\text { users with } \\
\text { comprehensive, } \\
\text { flexible, and (usually) } \\
\text { simple-to-understand } \\
\text { service plans }\end{array}$ \\
\hline Google's Gmail, Apps & $\begin{array}{l}\text { Microsoft's Azure, } \\
\text { Salesforce's } \\
\text { Force.com }\end{array}$ & $\begin{array}{c}\text { Amazon's Elastic } \\
\text { Compute Cloud (EC2), } \\
\text { Simple Storage } \\
\text { Service }\end{array}$ & Internet telephony \\
\hline
\end{tabular}

Sources: (Mell and Grance, 2011; Rao, et al., 2013)

Table 3. Deployment models of cloud computing

\begin{tabular}{|c|c|c|c|}
\hline Private cloud & Community cloud & Public cloud & $\begin{array}{l}\text { Hybrid (combined) } \\
\text { cloud }\end{array}$ \\
\hline $\begin{array}{l}\text { The cloud infrastructure is } \\
\text { provisioned for exclusive } \\
\text { use by a single organization } \\
\text { comprising multiple } \\
\text { consumers (e.g., business } \\
\text { units). It may be owned, } \\
\text { managed, and operated by } \\
\text { the organization, a third } \\
\text { party, or some combination } \\
\text { of them, and it may exist on } \\
\text { or off-premises }\end{array}$ & $\begin{array}{l}\text { The cloud infrastructure is } \\
\text { provisioned for exclusive } \\
\text { use by a specific } \\
\text { community of consumers } \\
\text { from organizations that } \\
\text { have shared concerns } \\
\text { (e.g., mission, security } \\
\text { requirements, policy, and } \\
\text { compliance } \\
\text { considerations). It may be } \\
\text { owned, managed, and } \\
\text { operated by one or more } \\
\text { of the organizations in the } \\
\text { community, a third party, } \\
\text { or some combination of } \\
\text { them, and it may exist on } \\
\text { or off-premises }\end{array}$ & $\begin{array}{l}\text { The cloud infrastructure } \\
\text { is provisioned for open } \\
\text { use by the general public. } \\
\text { It may be owned, } \\
\text { managed, and operated } \\
\text { by a business, academic, } \\
\text { or government } \\
\text { organization, or some } \\
\text { combination of them. It } \\
\text { exists on the premises of } \\
\text { the cloud provider }\end{array}$ & $\begin{array}{l}\text { The cloud infrastructure } \\
\text { is a composition of two } \\
\text { or more distinct cloud } \\
\text { infrastructures (private, } \\
\text { community, or public) } \\
\text { that remain unique } \\
\text { entities, but are bound } \\
\text { together by standardized } \\
\text { or proprietary technology } \\
\text { that enables data and } \\
\text { application portability } \\
\text { (e.g., cloud bursting for } \\
\text { load-balancing between } \\
\text { clouds) }\end{array}$ \\
\hline $\begin{array}{l}\text { HPE, IBM, Red Hat, } \\
\text { Microsoft }\end{array}$ & Google's GovCloud & $\begin{array}{c}\text { Amazon Elastic- } \\
\text { Compute-Cloud, IBM's } \\
\text { BlueCloud, Sun Cloud, } \\
\text { Google AppEngine, AWS }\end{array}$ & $\begin{array}{l}\text { HIPAA-compliant } \\
\text { hosting }\end{array}$ \\
\hline
\end{tabular}

Sources: (Mell and Grance, 2011; Yoo and Kim, 2018) 
Cloud computing is the combination of a technology, platform that provides hosting and storage service on the Internet (Lamba and Singh, 2011). In such an environment users don't need own infrastructure for various computing services, they can be accessed from any computer in any part of the world. This integrates features supporting high scalability and multitenancy, offering enhanced flexibility in comparison to the earlier existing computing methodologies. It can deploy, allocate or reallocate resources dynamically with an ability to continuously monitor their performance (Mell and Grance, 2011; Nazir, 2012). Moreover, cloud computing minimizes capital expenditure. This approach is device and user-location independent. The main goal of the cloud computing is to provide scalable and inexpensive on-demand computing infrastructures with good quality of service levels (Singh, et al., 2011; Nogueira, et al., 2016).

Cloud computing supports the ability to dynamically scale up and quickly scale down, offering cloud consumers high reliability, quick response times, and the flexibility to handle traffic fluctuations and demand (Vaquero, et al., 2009). Cloud computing also supports multi-tenancy, providing systems configured in such a way that they can be pooled to be shared by many organizations or individuals (Oliveira, et al., 2010). A.Weiss explained that the cloud computing concept was drawn on legacy architectures and technologies as various cloud shapes, software as a service, the data center, distributed computing, or a utility grid (Weiss, 2007). However, cloud computing is a compelling idea which incorporates all sorts of computing models.

Virtualization technology allows cloud vendors to convert one server into many virtual machines, thereby eliminating client-server computing with single-purpose systems (Foster, et al., 2008; Chandrasekaran, 2015). The most important benefit of cloud computing is that the customers don't need to buy the resource from a third party vendor, instead, they can use the resource and pay for it as a service thus helping the customer to save time and money. In (Varghese and Buyya, 2018) authors discussed what future cloud computing looks like by charting out trends and directions for pursuing meaningful research in developing next-generation computing systems.

Methodology and research methods. The cloud provider has the following advantages:

1.Reduction of expenditures for the organization of the data center and its maintenance.

2.Ability to rapid market penetration in the absence of construction of information structure during the long period.

3.Availability of high-performance applications for small and medium businesses.

4.Increasing the mobility of employees all around the world.

5. IE is a department focusing on innovation and the development of a new anti-IT department for the data center.

6.Unlimited scalability and flexibility.

7. «Greening» the data center by reducing idle capacity.

8. Improve reliability and guarantee uninterrupted work.

When it comes to startups or the significant expansion of reputable companies in the market, the economic feasibility of cloud computing is undeniable and obvious. In such situations, there is no need spending money and time on setting up personal data centers, their maintenance or service, recycling equipment or purchasing new ones, developing applications to integrate them with existing systems, retraining employees, etc. (Amokrane, et al., 2013; Armbrust, 2009; Church, et al., 2008).

The expenditure on organizing and maintaining a data center (DC) is the highest cost item at an enterprise. Such an item can be up to $50 \%$ of the total cost. However, it should be noted that the share of start-ups or emerging companies is not very significant. For large companies that have been in the market for a long time, the implementation of cloud computing can be associated with both revenue and expenditure. On the one hand, a company must make substantial investments, rebuild its existing business system and take on the risks that have not yet been fully examined. However, on the other 
hand, it is necessary to assess whether the absence of cloud computing will reduce the company's competitiveness in the future (Hao, et al., 2010; Jarray, 2012; Jarray, et al., 2015).

Some possible scenarios for the deployment of cloud technologies are shown in table 4 . According to the first scenario, the application is developed from scratch in compliance with the traditional model. In the second case, the elaboration is based on cloud technologies. Regarding the third scenario, the company already has a ready-made application and transmits it completely into clouds. With respect to the fourth scenario, the existing non-cloud application is still being used without its completion.

Table 4. Expenditures for different cloud computing scenarios

\begin{tabular}{|c|c|c|c|c|}
\hline \multirow[b]{2}{*}{$\begin{array}{c}\text { Types of } \\
\text { expenditures }\end{array}$} & \multicolumn{2}{|c|}{ Development of a new application } & \multirow{2}{*}{$\begin{array}{l}\text { Complete } \\
\text { conversion of the } \\
\text { application into } \\
\text { cloud technology }\end{array}$} & \multirow{2}{*}{$\begin{array}{l}\text { Continuing use of } \\
\text { the existing } \\
\text { application without } \\
\text { cloud technology }\end{array}$} \\
\hline & $\begin{array}{c}\text { according to } \\
\text { the traditional } \\
\text { model }\end{array}$ & $\begin{array}{l}\text { using cloud } \\
\text { technologies }\end{array}$ & & \\
\hline \multicolumn{5}{|l|}{ One-time: } \\
\hline on equipment & High & & None & \\
\hline $\begin{array}{l}\text { on development or } \\
\text { improvement of } \\
\text { the application }\end{array}$ & \multicolumn{2}{|c|}{ High } & Medium & High \\
\hline $\begin{array}{l}\text { recycling of } \\
\text { equipment }\end{array}$ & \multicolumn{2}{|c|}{ None } & Medium & None \\
\hline staff training & Law, medium & \multicolumn{2}{|c|}{ Medium } & None \\
\hline \multicolumn{5}{|l|}{ Period: } \\
\hline $\begin{array}{l}\text { to rent cloud } \\
\text { service }\end{array}$ & None & \multicolumn{2}{|c|}{ Medium } & None \\
\hline $\begin{array}{l}\text { on technical } \\
\text { support }\end{array}$ & None & \multicolumn{2}{|c|}{ Medium } & None \\
\hline on staff salaries & High & \multicolumn{2}{|c|}{ Medium } & High \\
\hline $\begin{array}{l}\text { to rent premises } \\
\text { and infrastructure }\end{array}$ & High & \multicolumn{2}{|c|}{ None } & High \\
\hline
\end{tabular}

Sources: compiled by the authors

In each scenario, it is essential to deal with one-time and period expenditures. One-time expenditures are only incurred in developing and implementing the application, and period expenditures occur regularly until the application is taken out of use.

The implementation of cloud technology not only completely eliminates expenditures related to the purchase and subsequent use of its own equipment, but also saves on the salaries of employees that should be responsible for the operation of the equipment, not the application (Zeng, et al., 2012).

For existing systems, the use of cloud technology allows getting rid of the period expenditures related to maintaining your own equipment. In this case, there are expenditures connected with redesigning the application and minimizing its personal data centre (PDC) [Unleashing the Potential]. Depending on the specific tasks and conditions of each organization, any of the scenarios described in the table may turn out to be most economically feasible. However, the use of cloud technology is attractive in that it frees up some of the money that would go toward solving non-core IT business tasks.

In (Armbrust, 2009) a formula for calculating the benefits of using cloud technologies of the following type is proposed:

$$
\operatorname{tcl}(\operatorname{Tr}-\mathrm{Ph} . c l) \geq t P D C\left(\operatorname{Tr}-\frac{P h . P D C}{U}\right),
$$

where $t c l$ - used hours of cloud; $T r$ - income; Ph. $c l$ - the cost of one hour of cloud; $t P D C$ hours used by the DC; Ph.PDC - the cost of one hour of the DC; $U$-average utilization of the DC. 
This formula assumes that the private cloud is also considered as personal data center, and the cloud itself refers to external clouds (cloud service providers).

The left part of the formula represents the revenue that a company can receive using cloud computing, based on the specified hours of machine time. The right part of the formula constitutes the revenue that a company can receive when using its PDC.

The difference is that, according to formula (1), when using its PDC, the factor of average capacity utilization should be considered. For instance, if DC capacities are used by only $10 \%$, then, when calculating the revenue of the cost of one hour, the data center is multiplied by 10 , which reduces the income of this option [OpenStack].

Economically, the option of the average DC utilization that is close to 1 is considered to be ideal. However, it should also be noted that formula (1) does not consider:

- the period for which the income are compared (left and right parts of the inequality), should be the same;

- $100 \%$ - the average utilization in practice is unattainable (such a situation is evidence of catastrophic capacity overload, the optimal utilization of the data center varies between values of 60 $70 \%)$;

- the cost of one hour of DC already contains excess prices at above average load. Unloaded equipment is purchased, connected, then software is purchased and installed on it, equipment is maintained in working order, consumes electricity; the service personnel is also hired considering all the capacity, not the actual utilization. Thus, by dividing the expenditures per one hour of the DC on the average utilization in accordance with formula (1) the cost of the DC unreasonably increases.

To account for these factors, the cost of one hour of $D C$ was replaced by the average cost of using data center capacities, that is, the cost of the average DC utilization without taking into account the cost of holding excess capacity. In this case, the problem is that the cost of the used DC capacities is not an obvious parameter for the enterprise and requires calculations (Gorobets, 2012).

Using all of the provided observations and disadvantages, the following inequality is proposed to calculate the benefits of cloud computing:

$$
\frac{T r c l-T c c l}{t c l} \geq \frac{\operatorname{TrPDC}-T C P D C}{t P D C},
$$

where $\operatorname{Tr} c l$ - revenue from the use of cloud services for the period $t c l$; $\operatorname{Tr} P D C$ - revenue using its PDC for the period $t P D C$; Tccl - expenditures on cloud services for the period tcl;TcPDC comprehensive $D C$ costs $t P D C$, including the average cost of the $D C$ equipment (the initial cost of the equipment divided into the entire cycle of use and multiplied by the period under consideration), as well as the cost of maintaining its PDC for the same period, considering staff salaries, acquisition software and bill payment (Greenberg, et al., 2009).

In formulas (1) and (2), the DC is the property of the company and does not apply to cloud computing even if its capabilities suggest cloud characteristics.

To calculate long-term benefits, a considerable period of time must be taken into account and a shorter period to calculate short-term prospects. It should be considered the average period according to the annual demand period; this is relevant for «seasonal» types of business, for instance, in a one-year period. Then the above formula (2), will have the following form:

$$
T r c l-T c c l \geq T r P D C-T c P D C .
$$


As already mentioned, the average utilization as a divisor for display in formula (2) of listed factors should not be included in the formula (3), since the specified values have already included its excess value over the required period (extra capacity, staff salaries, servicing costs of excess capacity during the given period). The equation can also be expressed through the average utilization for the benefits of enterprises with seasonal business.

If we take $60 \%$ as optimal utilization of $\mathrm{DC}$, then:

$$
\operatorname{Tcrec} P D C=\frac{T c u s P D C}{0,6} \approx \frac{T c P D C \cdot U m}{60},
$$

where $U m$ - average utilization for the period, $\%, 0 \leq U m \leq 100 ;$ TcrecPDC - expenditures on the required DC capacity for the period; TcusPDC - expenditures on the effectively used DC capacity for the period.

Equality (4) is approximate since expenditures on used and unused DC capacity are generally not the same (for instance, the cost of unused capacities may be lower due to reduced power consumption and low amortization of equipment).

Therefore, the extra cost (Tcext) of maintaining its PDC for the period will be:

$$
\begin{gathered}
\text { Tcext }=T c P D C-T \operatorname{crec} P D C=T c P D C-\frac{T c u s P D C}{0,6} \approx \\
T c P D C\left(1-\frac{U m}{60}\right)=\frac{T c P D C(60-U m)}{60} .
\end{gathered}
$$

A cloud service provider can offer a lower cost by reducing extra expenditures because he has a fairly high level of average utilization due to the large size of the DC and a great number of consumers. In conformity with that, on the approach to the average utilization for the period to the optimal utilization (about 60\%), the extra cost will be 0 .

Let's represent (3) considering average utilization and extra costs, to show the inverse proportionality of average utilization and expenditures, as well as the real benefits of using cloud technology in the case of uneven utilization in the form of (for $0 \leq U m \leq 60 \%$ ):

$$
\operatorname{Trcl}-\operatorname{Tccl} \geq \operatorname{Tr} P D C-\frac{60 T c r e c P D C}{U m} .
$$

For $U m \geq 60 \%$ possible system failure and the following scenarios:

1) decrease in revenue by a loss factor $(\mathrm{k}) \operatorname{Trcr} P D C=\operatorname{Trreg} \cdot k$, where $\operatorname{Trcr} P D C$ - revenues for the critical period of DC use with a load more than $60 \%$; Trreg - revenues for the regular period;

2) complete loss of income $\operatorname{Tr} P D C=0$;

3) significant losses $\operatorname{Tr} P D C\langle T C P D C$.

The higher utilization is the lower expenditures on maintaining a DC. According to (6), the use of public cloud services is more advantageous than the lower capacity utilization of the DC. In addition, the choice of cloud computing is appropriate even when it is impossible to predict medium and maximum utilization in advance. Consequently, the appeal of cloud computing is obvious:

- for startups, the cost of one hour of PDC will be too high due to the higher costs of purchasing equipment from scratch and recruitment process;

- a clear benefit to seasonal businesses and businesses with a large dispersion of DC utilization (for instance, touristic operators, online stores, etc.); 
- the benefit is for businesses with low or poorly anticipated hardware capacity utilization. If the utilization turns out to be significantly lower than expected, then the enterprise will have no need to overpay for idle capacity, and if it exceeds expectations, it is much easier to add insufficient cloud-based resources than to purchase additional equipment for installation at its PDC.

For long-established companies in the market, the benefit is also significant, because according to IT analysts, the average utilized capacity of the DC is $18 \%$, and for servers architecture - the $x 86$, this indicator is reduced to $12 \%$ (Frolov and Podlevskih, 2015). For such companies it is recommended to make a gradual transition to cloud computing, as it is necessary to start with small projects. This will allow avoiding the risks and «shocking situations» and also evaluate the actual benefits of implementing cloud computing (Chernomorov, 2005).

It has become clear that the primary task of the organization is to determine the relevance of using cloud services as an alternative to its PDCs. A decision-making is needed to compare expenditures on using cloud technology and expenditures on PDC. The presented model of estimation of cloud computing implementation efficiency at enterprises reflects the benefits from the use of these technologies.

Empirical results. We will evaluate the efficiency and relevance of the cloud computing implementation in accordance with the model presented and a simplified methodology for calculating the total cost of ownership.

In [Armbrust, 2009], the main positive characteristic of cloud services is flexibility (Rangan, 2008; Siegele, 2008). Let's consider the following situation (table 5, fig. 1).

Table 5. Demand of the computing system during the day

\begin{tabular}{|c|c|}
\hline Time of the day & Demand, number of servers \\
\hline $6: 00$ & 100 \\
\hline $12: 00$ & 500 \\
\hline $16: 00$ & 400 \\
\hline $20: 00$ & 300 \\
\hline $0: 00$ & 100 \\
\hline
\end{tabular}

Sources: compiled by the authors

According to the above condition, there is peak demand for computing technology (the need for 500 servers in the middle of the day). The lowest demand is observed at midnight and in the morning. The average demand for technology is 280 servers. That is, during the day, the company uses $280 \cdot 24=6720$ servers-hours, which are paid at a certain rate, considering all costs of maintaining the DC.

However, if we consider using your PDC at an enterprise, then it is needed to support all 500 DC servers throughout the day to fully meet the demand for computing technology. In other words, an enterprise may pay $500 \cdot 24=12000$ serves-hours.

Thus, it can be concluded that it would be more profitable for the enterprise to maintain its PDC at the level of demand of 280 servers, and during periods of peak demand to rent cloud technologies. This would save on the cost of maintaining your PDC.

In papers (Hamilton, 2009; Hamilton, 2008), the formula for calculating the feasibility of using cloud computing was considered, which for the usability in the following experiments is written as: 


$$
t c l \cdot(\operatorname{Trcl}-T c c l) \geq t P D C \cdot\left(\operatorname{Tr} P D C-\frac{T c P D C}{U m}\right),
$$

where $t c l$ - number of hours of cloud services used; $T r c l$ - income from cloud computing; $T c c l$ the cost of one hour of cloud services; $t P D C$ - the number of hours of PDC; $\operatorname{Tr} P D C$ - income from using PDC; TCPDC - the cost of one hour of using PDC; $U m$ - average data center utilization.

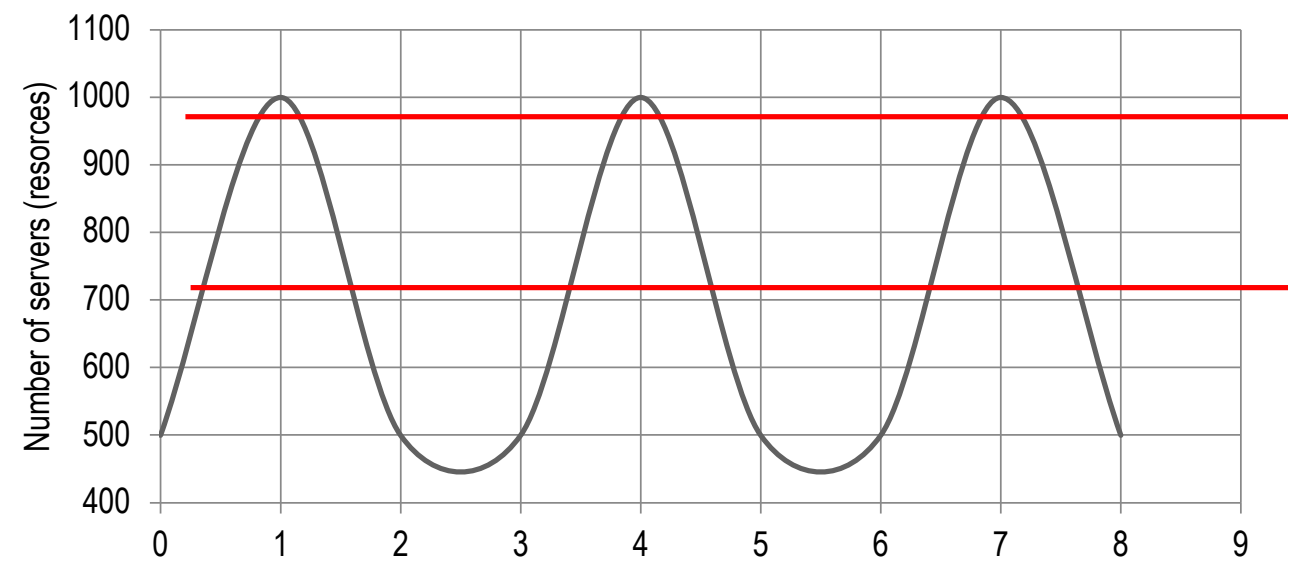

Figure 1. Display fluctuations in demand for computing technology throughout the day Sources: compiled by the authors

According to the above model, we will conduct the following experiment.

The following characteristics are taken as initial data: one business process at an enterprise generates new data with an average volume of $500 \mathrm{~GB}$; the processing time of $1 \mathrm{~GB}$ of data on its PDC is 2 hours; the enterprise DC consists of 20 servers; the cost of an hour of data processing is $0.1 \mathrm{UAH}$. Thus, the cost of processing $500 \mathrm{~GB}$ of information on your PDC for the enterprise will be:

$\frac{500 \cdot 2}{20} \cdot 0,1=5 \mathrm{UAH}$.

The enterprise has the opportunity to rent a cloud service with the following conditions: processing time of $1 \mathrm{~GB}$ of information is 1 hour, the cost of an hour of data processing is $0.1 \mathrm{UAH}$, the speed of information transfer to the service is $0.0028 \mathrm{~GB} / \mathrm{s}$. In this case, the cost of using cloud services will be: $\frac{500}{0,0028 \cdot 3600} \cdot 0,1=5,06 \mathrm{UAH}$. Therefore, in this case, the use of cloud technology is not justified.

However, it should be noted that the modern development of cloud technologies can significantly increase not only the speed of data transfer, but also the speed of calculations due to the higher capacity and the number of servers for computing. We will carry out additional experiments to calculate the cost of DC at our PDC and using a cloud service (Table 6).

As we can see, it is enough to increase the data transfer rate to $0.00284 \mathrm{~GB} / \mathrm{s}$, and the benefit of using the cloud service will be $0.19 \%$. In addition, according to the results of the experiments, it can be concluded that increasing the amount of data for processing under unchanged other conditions, increases the benefit of using cloud computing. 
Table 6. Results of experiments regarding comparison of the cost of calculations on PDC and

\begin{tabular}{|c|c|c|c|c|c|c|c|c|c|c|}
\hline \multicolumn{11}{|c|}{ using a cloud service } \\
\hline 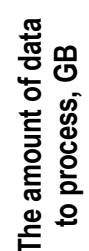 & 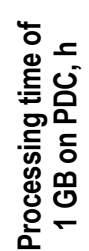 & 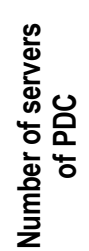 & 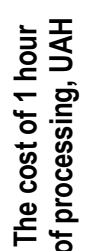 & 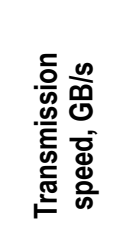 & 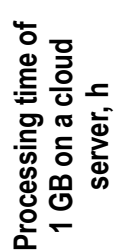 & 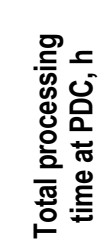 & 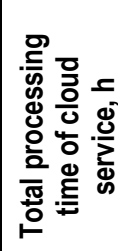 & 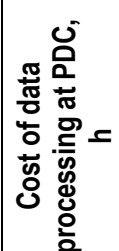 & 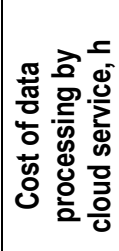 & 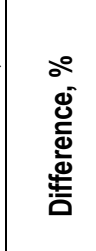 \\
\hline 500 & 2 & 20 & 0,1 & 0,00280 & 1 & 50,00 & 50,60 & 5,00 & 5,06 & $1,21 \%$ \\
\hline 500 & 2 & 20 & 0,1 & 0,00284 & 1 & 50,00 & 49,90 & 5,00 & 4,99 & $-0,19 \%$ \\
\hline 2000 & 2 & 20 & 0,1 & 0,00284 & 1 & 200,00 & 196,62 & 20,00 & 19,66 & $-1,69 \%$ \\
\hline & 2 & 20 & 0,1 & & 1 & & & & 49,00 & $-1,99 \%$ \\
\hline 10000 & 2 & 20 & 0,1 & 0,00284 & 1 & 1000,00 & 979,09 & 100,00 & 97,91 & $-2,09 \%$ \\
\hline 000 & 2 & 20 & 0,1 & 0,00284 & 1 & 5000,00 & 4891,45 & 500,00 & 489,15 & $-2,17 \%$ \\
\hline
\end{tabular}

Sources: compiled by the authors

Let's evaluate the efficiency of cloud computing implementation at the enterprise by a simplified method of calculating the total cost of ownership. In the general case, the TCO is estimated by the formula (Frolov and Podlevskih, 2015):

$$
T c o=K+C \cdot t,
$$

where $\mathrm{C}$ - operating costs; $\mathrm{K}$ - capital costs; $\mathrm{t}$ - planned number of years of operation.

Capital costs are paid only once at the beginning of IT implementation. This indicator for the cloud computing system $(\mathrm{Kcc})$ characteristics are by the formula:

$$
K c c=K h c+K s c+K t+K s t+K s e,
$$

where Khc - hardware costs; $K s c$ - software costs; $K t$ - telecommunication costs; $K s t$ - staff training costs; Kse - setup costs.

The implementation of cloud computing reduces expenditures on your own equipment and costs connected with the remuneration of workers that serving the information system.

Capital costs for personal computing system:

$$
K P D C=K d+K h c+K s c+K t+K s t+K s e,
$$

where $K d$ - expenditures on designing (expenditures on designers' salaries, expenditures on software, design, expenditures on computer hardware for design, etc.); Khc - hardware costs; Ksc software costs; $K t$ - telecommunication costs; $K s t$ - staff training costs; $K s e$ - setup costs.

Operating costs are incurred each production cycle. For the cloud system:

$$
C c c=C s s+C c s+C i s+C t o t
$$

where $C s s$ - expenditures on staff salary; $C c s$ - expenditures on paying cloud services; $C i$ expenditures on paying Internet services; Ctot - total expenditures, including electricity costs, materials, other expenses. 
For its PDC, operating expenses are:

$$
C P D C=C s s+C a m+C i+C m+C t o t,
$$

where Css - expenditures on staff salary; Cam - expenditures on amortization; $\mathrm{Ci}$ - expenditures on paying Internet services; $\mathrm{Cm}$ - maintenance expenditures; $\mathrm{Ctot}$ - total expenditures, including electricity costs, materials, other expenses.

In order to compare expenditures on operating its PDC and expenditures on implementation of cloud technologies, the calculations were made for the following input data: for the implementation of cloud computing, the enterprise needs to reconfigure the hardware for the amount of 37 thousand $\mathrm{UAH}$, software valued at 8.5 thousand UAH and to train the staff, which will cost 5 thousand UAH for one person. Expenditures on implementation of its PDC will include the hardware and software costs, priced at 50 thousand $\mathrm{UAH}$ and 10 thousand $\mathrm{UAH}$ respectively. The telecommunications organization requires a cost of 9 thousand $\mathrm{UAH}$, and staff retraining -5 thousand $\mathrm{UAH}$ for one person.

The components of capital expenditures for both options are included in the table 7.

Table 7. Enterprise capital expenditures on cloud computing and personal computing center

\begin{tabular}{|l|c|c|}
\hline \multirow{2}{*}{ Indicator } & \multicolumn{2}{c|}{ Capital expenditures, UAH } \\
\cline { 2 - 3 } & Personal computing system & Cloud computing \\
\hline Design costs & 25000 & - \\
\hline Hardware costs & 50000 & 37000 \\
\hline Software costs & 10000 & 8500 \\
\hline Telecommunication costs & 9000 & 9000 \\
\hline Staff training costs & 5000 & 5000 \\
\hline Installation and setup of the equipment costs & 3000 & 3000 \\
\hline \multicolumn{1}{|c|}{ Sum } & $\mathbf{1 0 2 0 0 0}$ & $\mathbf{6 2 5 0 0}$ \\
\hline
\end{tabular}

Sources: compiled by the authors

The next step is to calculate the operating expenses for both options. The components of operating expenses are given in table 8.

Table 8. Operating expenditures of the enterprise for the implementation of cloud computing and its personal computing center

\begin{tabular}{|l|c|c|}
\hline \multirow{2}{*}{ Types of expenditures } & \multicolumn{2}{c|}{ Operating costs, UAH } \\
\cline { 2 - 3 } & Cloud computing & Personal computing system \\
\hline On staff salaries & 216000 & 216000 \\
\hline To pay cloud service & 14500 & - \\
\hline On amortization & - & 9500 \\
\hline To pay for Internet service & 10000 & 10000 \\
\hline On maintenance & - & 192000 \\
\hline Others & - & 7500 \\
\hline \multicolumn{1}{|c|}{ Sum } & $\mathbf{2 4 0 5 0 0}$ & $\mathbf{4 3 5 0 0 0}$ \\
\hline
\end{tabular}

Sources: compiled by the authors 
Therefore, we received capital and operating costs for two options. It is now necessary to calculate the common indicators for both cases in compliance with the method of total cost of ownership (Frolov and Podlevskih, 2015):

1) for an enterprise that uses cloud computing:

$$
\text { TCOCc }=62500+240500=303000 .
$$

2) for an enterprise that implements its personal data center:

$$
\text { TCOdc }=102000+435000=537000 .
$$

The obtained results are examined within 5 years and are shown in Fig. 2.

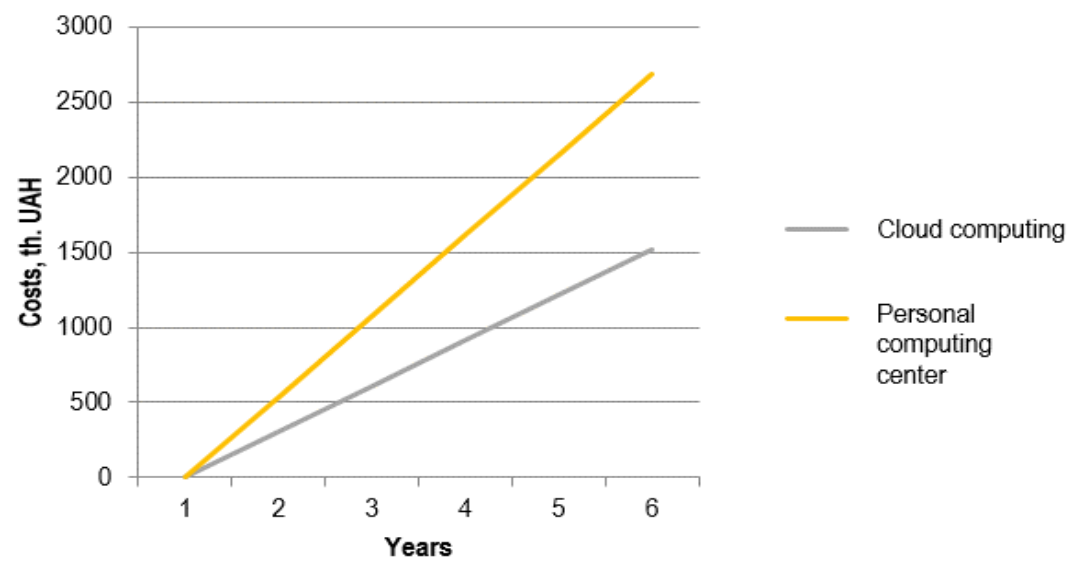

Figure 2. Expenditure indicators for cloud computing projects and personal computing center Sources: compiled by the authors

On the basis of all conducted calculations, conclusions ought to be drawn on the implementation of cloud computing or the introduction of its PDC. However, it should be noted that the implementation of enterprise cloud technology is appropriate and effective for organization, as evidenced by statistics (table 9).

Table 9. Comparison of cost of using PDC and cloud computing with the savings rate

\begin{tabular}{|l|c|c|c|}
\hline \multicolumn{1}{|c|}{ Cost item } & $\begin{array}{c}\text { Cost of using } \\
\text { PDC }\end{array}$ & $\begin{array}{c}\text { Cost of using cloud } \\
\text { computing }\end{array}$ & Savings rate \\
\hline $\begin{array}{l}\text { Network infrastructure and } \\
\text { storage }\end{array}$ & $\begin{array}{c}\sim 2500 \text { UAH per } \\
\text { month }\end{array}$ & $\sim 970$ UAH per month & 2,5 \\
\hline Administration & $\begin{array}{c}\sim 150 \text { servers per } \\
\text { admin }\end{array}$ & $>1000$ servers per admin & 6,7 \\
\hline
\end{tabular}

Sources: compiled by the authors according to sources (The official sites of the companies «De Novo», «Integrity Systems», «Soft Line», «Valtek», «Volia»)

Conclusions. The basic characteristics, types and properties of cloud computing are described. It is identified that cloud technologies offer a wide range of services, the most common in Ukraine are laaS infrastructure as a service, SaaS-storage as a service and PaaS-platform as a service. The main benefits of using cloud computing are found to be their flexibility and ability to access up-to-date 
information at any time and from any device. The biggest drawback of technology for users is the dependence on the Internet and the lack of guaranteed security and confidentiality of information. It is revealed that at the moment the largest share among the users of cloud technologies in Ukraine belongs to trading companies and banks, but other sectors of business are also involved in the development of these services.

A series of experiments were conducted to investigate the model of estimating the efficiency of cloud computing implementation at enterprises, which confirm the cost-effectiveness of using cloud technologies by organizations. The efficiency of cloud computing using the methodology of determining total cost of ownership is proved.

Thus, cloud computing is an advanced technology that has future prospects and is cost-effective for both enterprise users and provider organizations. The efficiency of cloud technologies depends on the internal structure and organization of the computing processes within the systems, as well as on external factors, such as the size of enterprises-customers, industries, expenditures to set up data centers, etc.

Author Contributions: conceptualization, T.Z. and O. D.; methodology, T.Z.; software, T.Z.; validation, T. Z. and O. D.; formal analysis, O. D.; investigation, T. Z.; resources, O. D.; data curation, T. Z.; writing - original draft preparation, T.Z.; writing - review and editing, O. D. and T. Z.; visualization, T. Z.; supervision, T. Z.; project administration, T. Z.; funding acquisition, O. D.

\section{References}

Ahmed, A.A., Hussan, M.I. (2018). Cloud computing: study of security issues and research challenges. International Journal of Advanced Research in Computer Engineering \& Technology, Vol.7(4), 2278-1323.

Amokrane, A., Zhani, M.F., Langar, R., Boutaba, R., Pujolle, G. (2013). Greenhead: Virtual Data Center Embedding across Distributed Infrastructures. IEEE Transactions On Cloud Computing, Vol.1, №1.

Armbrust, M. (2009). Above the Clouds: A Berkeley View of Cloud Computing. Electrical Engineering and Computer Sciences, University of California at Berkeley. Technical Report UCB/EECS-2009-28.

Buyya, R., Yeo, C. Venugopal, S. (2008). Market-oriented cloud computing: vision, hype, and reality for delivering IT services as computing utilities. 10th Proceedings IEEE, 5-13.

Chandrasekaran, K. (2015). Essentials of cloud computing. London: Taylor \& Francis Group. 396 p.

Chernomorov, G.A. (2005). Theory of decision making. Tutorial. Novocherkassk. 448 p.

Church, K., Hamilton, J., Greenberg, A. (2008). On delivering embarrassingly distributed cloud services. Hotnets

Dluhopolskyi, O., Dluhopolska, T., Farion, A., Zhukovska, A., Kryvokulska, N. (2019). The Implementation of the E-health System and Anticorruption Reforms (Case of EU Countries for Ukraine). 9th International Conference on Advanced Computer Information Technologies, ACIT 2019 - Proceedings. (5-7 June 2019, Ceske Budejovice, Czech Republic).

Farion, A., Dluhopolskyi, O., Banakh, S., Farion, M., Ivashuk, Y. (2019). Using blockchain Technology for Boost Cyber Security. 9th International Conference on Advanced Computer Information Technologies, ACIT 2019 - Proceedings. (5-7 June 2019, Ceske Budejovice, Czech Republic).

Foster, I., Zhao,Y., Raicu, I., Lu, S. (2008). Cloud Computing and Grid Computing 360-Degree Compared. Grid Computing Environments Workshop.

Frolov, A.L., Podlevskih, A.P. (2015). Otsenka effektivnosti vnedreniya v deyatelnost organizatsii oblachnyih tehnologiy na osnove uproschennoy metodiki rascheta sovokupnoy stoimosti vladeniy [Evaluation of the effectiveness of implementing cloud technologies in the organization's activities based on a simplified methodology for calculating the total cost of ownership] Fundamentalnyie issledovaniya, Vol.11(5), 1048-1053 [in Russian].

Gohin, B., Narayanan, R., Vinod, V. (2012). Cloud Computing Architecture for Visual Disabilities on E-Governance. International Journal of Computer Applications, Vol.52(1), 44-46.

Gorobets, V.V. (2012). The model of on-line transaction processing system in the cloud environment Novocherkassk: LIK, 157-159.

Greenberg, A., Hamilton, J., Maltz, D.A., Patel, P. (2009). The Cost of a Cloud: Research Problems in Data Center Networks. ACM SIGCOMM Computer Communication, Vol.39, Issue 1, 68-73.

Hamilton, J. (2008). Cost of Power in Large-Scale Data Centers. Retrieved from: http://perspectives.mvdirona.com/ 2008/11/28/CostOfPowerlnLargeScaleDataCenters.asp 
Hamilton, J. (2009). Cooperative Expendable Micro-Slice Servers (CEMS):Low Cost, Low Power Servers for Internet-Scale Services. Conference on Innovative Data Systems Research. CIDR 09. January.

Hao, F., Lakshman, T. V., Mukherjee, S., Song, H. (2010). Secure Cloud Computing with a Virtualized Network Infrastructure. HotCloud '10: Proceedings of the 2nd USENIX conference on Hot topics in cloud computing.

Jarray, A. (2012). DDP: A Dynamic Dimensioning and Partitioning model of Virtual Private Networks resources. Computer Communications, Vol.35, 906-915.

Jarray, A., Salazar, J., Karmouch, A., Elias, J., Mehaoua, A. (2015). QoS-based Cloud Resources Partitioning Aware Networked Edge Datacenters. Retrieved from: http://www.math-info.univ-paris5.fr/ jelias/papers/qos_resources_networked EdgeDatacenters_IM2015.pdf

Lamba, H.S., Singh, G. (2011). Cloud Computing-Future Framework for e-management of NGO's. JoAT, Vol.2(3).

Mell, P., Grance, T. (2011). The NIST Definition of Cloud Computing. Recommendations of the National Institute of Standards and Technology. Special Publication, 800-145.

Nazir, M. (2012). Cloud Computing: Overview \& Current Research Challenges. IOSR Journal of Computer Engineering, Vol.8(1), 14-22.

Nogueira, E., Moreira, A., Lucrédio, D., Garcia, V., Fortes, R. (2016). Issues on developing interoperable cloud applications: definitions, concepts, approaches, requirements, characteristics and evaluation models. Journal of Software Engineering Research and Development, Vol.4(7).

Oliveira, D., Baião, F., Mattoso, M. (2010). Towards Taxonomy for Cloud Computing from an e-Science Perspective. Cloud Computing: Principles, Systems and Applications, Heidelberg: Springer-Verlag.

OpenFlow - Enabling Innovation in Your Network. Retrieved from: http://www.openflow.org/

OpenStack Open Source Cloud Computing Software. Retrieved from: http://www.openstack.org/

Rangan, K. (2008). The Cloud Wars: \$100+ billion at stake. Tech. rep. Merrill Lynch.

Rao, Ch., Leelarani, M., Kumar, Y.R. (2013). Cloud: Computing Services And Deployment Models. International Journal Of Engineering And Computer Science, Vol.2(12), 3389-3392.

Siegele, L. (2008). Let It Rise: A Special Report on Corporate IT. The Economist.

Singh, G., Sood, S., Sharma, A. (2011). Measurement Facets for Cloud Performance. JCA, Vol.23(3).

The official site of the company «De Novo». Retrieved from: http://www.de-novo.biz/uk/

The official site of the company «Integrity Systems». Retrieved from: http://integritysys.com.ua/solutions/pricatecloud-solution/

The official site of the company «Soft Line». Retrieved from: http://www.softline.kiev.ua/ua/vidi-khmar/554-gibridnakhmara.html

The official site of the company «Valtek». Retrieved from: http://valtek.com.ua/ua/taxonomy/term/term/109

The official site of the company «Volia». Retrieved from: http://volia.com/ukr/about/pr/1363/

Unleashing the Potential of Cloud Computing in Europe. European Commission / Brussels, 27.9.2012COM529. Retrieved from: http:/lec.europa.eu/information_society/activities/cloudcomputing/docs/com/com_cloud.pdf

Vaquero, L.M., Rodero-Merino, L., Caceres, J., Lindner, M. (2009). A break in the clouds: towards a cloud definition. SIGCOMM Computer Communication Review, Vol.39(1), 50-55.

Varghese, B., Buyya, R. (2018). Next generation cloud computing: New trends and research directions. Future Generation Computer Systems, Vol.79, 849-861.

Weiss, A. (2007). Computing in the clouds. Network, Vol.11, 16-25.

Yoo, S.-K., Kim, B.-Y. (2018). A Decision-Making Model for Adopting a Cloud Computing System. Sustainability, Vol.10.

Zatonatska, T., Dluhopolskyi, O., Chyrak, I., Kotys, N. (2019). The internet and e-commerce diffusion in European countries (modeling at the example of Austria, Poland and Ukraine). Innovative Marketing, Vol.15(1), 66-75.

Zeng, L., Zeng, Z., Ye, X. (2012). Multi-objective Optimization Based Virtual Resource Allocation Strategy for Cloud Computing. IEEE/ACIS.

Т. Г. Затонацька, д.е.н., професор, Київський національний університет імені тараса Шевченка (Україна);

О. В. Длугопольський, д.е.н, професор, Тернопільський національний економічний університет (Україна).

Моделювання ефективності впровадження хмарних обчислень на підприємствах

У статті наведено основні характеристики, види та властивості хмарних обчислень. Проаналізовано найпошириніши в україні хмарні технології. Виявлено, що на даний момент найбільша частка серед користувачів хмарними технологіями в Україні належить великим холдінгам, IT- компаніям, торговим підприємствам та банкам, однак інші сектори господарської діяльності також залучаються до освоєння даних послуг. Метою статті є розробка методики щодо оцінки ефективності впровадження хмарних технологій на підприємствах та ї̈ експериментальне підтвердження. Розглянуто економічну складову від впровадження на підприємствах хмарних обчислень (видатки та доходи як власників хмарних технологій, так $і$ користувачів). Доведено ефективність використання хмарних обчислень на підприємствах. З'ясовано, що зазвичай організації не використовують потужності власних обчислювальних центрів повною мірою. Це призводить до простоювання обладнання, зайвих витрат на утримання та обслуговування апаратної частини, амортизаційні відрахування, оплату праці 
персоналу та інше. Доведено доречність переходу підприємств в таких ситуаціях до хмарних обчислень, які значно знижують витрати підприємства за рахунок відсутності потреби в апаратному забезпеченні та значного зниження необхідного персоналу для підтримки роботи інформаційних систем. Підтверджено зручність використання для оцінки ефективності функціонування хмарних обчислень методики сукупної вартості володіння. Запропонована методика дозволяє порівняти основні витрати на використання власних центрів обчислювання даних та витрати на застосування хмарних обчислень. Експериментально доведено, що в більшості випадків витрати на утримання власного центру обчислювання даних (ЦОД) є більшими за витрати на хмарні послуги. Доведено, що ефективність функціонування хмарних технологій залежить від внутрішньої структури та організації обчислювальних процесів всередині систем, так і від зовнішніх факторів, таких як розміри підприємств - клієнтів, галузей, витрат на організацію центрів обчислювання даних тощо. Хмарні обчислення є передовою технологією, що має перспективи у майбутньому і $є$ економічно вигідною як для підприємств - користувачів, так ідля організацій - провайдерів.

Ключові слова: хмарні обчислення, розподілена база даних, хмарні технології на підприємствах, ефективність функціонування хмарної обчислювальної системи, хмарна архітектура.

Manuscript received: 28.07.2019.

(c) The author(s) 2019. This article is published with open access at Sumy State University. 